\author{
Tamara Graczykowska \\ Uniwersytet Kazimierza Wielkiego \\ Bydgoszcz
}

\title{
SŁOWNIK JÓZEFA KRASNEGO A ŻYWY POLSKI JĘZYK RADZIECKI W DWUDZIESTOLECIU MIĘDZYWOJENNYM (KILKA UWAG O KONKURSIE OGLOSZONYM PRZEZ „TRYBUNĘ RADZIECKĄ” W 1930 ROKU)
}

W 1931 roku ukazał się w Moskwie słownik polsko-rosyjski, w 1933 - rosyjsko-polski ${ }^{1}$. Redaktorem naczelnym został Józef Krasny (właściwe nazwisko Rotstad) ${ }^{2}$. W skład redakcji weszli: S. L. Boltz, S. Z. Borski, S. R. Butkiewicz, G. G. Kamieński, F. B. Korecka, F. M. Gruszycki i S. Unszlicht. W przedmowie do drugiego tomu słownika redaktorzy pisali, że bardzo dokładnie dobierali terminologię społeczno-polityczną, ekonomiczną, techniczną, naukową i wojskową. Zdawali sobie jednak sprawę z tego, że ogólny słownik przekładowy nie powinien zastępować słowników specjalistycznych. Jednocześnie starali się przedstawić na kartach słownika nową, porewolucyjną terminologię polsko-radziecką, używaną przez Polaków mieszkających w Rosji radzieckiej. W słowniku znalazły się przede wszystkim te sowietyzmy ${ }^{3}$, które były w powszechnym obiegu wśród ówczesnej Polonii radzieckiej i zyskały charakter międzynarodowy ${ }^{4}$.

Te niezwykle cenne słowniki zasługują na szczególne zainteresowanie badaczy. Jak pisał Jan Wawrzyńczyk, są one „wartościowym źródłem dokumentacyjnym godnym uwagi historyka polskiego słownictwa"5. Do tej pory pojawiło się kilka artykułów, w których zajmowano się słownikami zredagowanymi przez Józefa Krasnego ${ }^{6}$.

1 Ю. Красный (ред.), Польско-русский словарь, Москва 1931; Ю. Красны й (ред.), Русско-польский словарь, Москва 1933.

${ }^{2}$ Szerzej zob.: K. Sierocka, Polonia radziecka 1917-1939. Z działalności kulturalnej i literackiej, Warszawa 1968, s. 40-42.

3 Termin „sowietyzm” nie ma tu jeszcze odcienia negatywnego, oznacza wszelkie pojęcia związane z życiem w państwie radzieckim.

4 Ю. Красны й, Русско-польскиц̆..., с. 1-2.

5 J. Waw rzyńczyk, O pewnym źródle dokumentacyjnym słownictwa polskiego, „Poradnik Językowy" 1990, nr 1, s. 57.

6 Й. Мэндэльска, Проблемы исследования послереволюционного варианта советского польского языка, „Scando-Slavica” t.47, 2001, s.3-61; J. Mędelska, Nowe, radzieckie realia odzwierciedlone 
Już w trakcie prac leksykograficznych słownik Józefa Krasnego wzbudzał duże zainteresowanie wśród Polonii radzieckiej.

W nr. 2 „Kultury Mas” z 1930 roku Bruno Jasieński in informował czytelników o trwających pracach leksykograficznych. Autor zarzucał komisji pracującej nad słownikiem całkowite oderwanie od mas proletariackich i tworzenie słownika w zaciszu gabinetów. Według Jasieńskiego słownik, który trafi w ręce czytelnika, będzie dziełem jednostek i wprowadzi do obiegu „nową terminologię drogą swoistego dekretu”.

Być może pod wpływem zarzutów sformułowanych przez Brunona Jasieńskiego Józef Krasny za pośrednictwem „Trybuny Radzieckiej”, w imieniu redakcji zajmującej się tworzeniem słownika polsko-rosyjskiego i rosyjsko-polskiego, zwrócił się do czytelników gazety $\mathrm{z}$ apelem, by wzięli udział w pracach przygotowawczych: „W tym niełatwym na ogół zadaniu najtrudniejszą sprawą jest przetłomaczenie, względnie spolszczenie wyrazów rosyjskich mniej znanych i powstałych w nauce i praktyce życia radzieckiego [...]. Dla ułatwienia tego zadania postanowiliśmy zwrócić się o pomoc do szerokiego aktywu polskiego. W «Trybunie Radzieckiej» będziemy drukowali spisy wyrazów rosyjskich, dla których brak polskich wyrazów, albo używane są nieodpowiednio, niezgodnie z duchem języka polskiego"9. Dalej czytamy: „Wydaje się nam, że czytelnicy «Trybuny Radzieckiej» i aktyw polski zupełnie dobrze uświadamiają sobie znaczenie słownika polsko-rosyjskiego i że otrzymamy od nich pomoc, o którą prosimy"10.

Na łamach „Trybuny Radzieckiej” Józef Krasny opisywał również, jak powstawał słownik. W nr. 54 z 1930 roku zanotowano: „Słownik polsko-rosyjski jest wydawnictwem podjętym przez redakcję Słowników przy Encyklopedii Sowieckiej. Redakcja ta postanowiła naprzód wydać część polsko-rosyjską, a następnie rosyjsko-polską. Aczkolwiek sprawę wydania słownika zadecydowano już w grudniu 1929 r., przystąpiono do właściwej pracy o wiele później z powodu braku materiału, który obstalowano w Polsce. Głównie chodziło o słowniki specjalne: techniczny, rzemieślniczy, elektrotechniczny itd. Obecnie nie otrzymaliśmy jeszcze wszystkich obstalowanych

w moskiewskim słowniku rosyjsko-polskim, wydanym w latach 30. ubiegłego wieku, [w:] Język, społeczeństwo, wartości, red. E. Laskowska, I. Benenowska, M. Jaracz, Bydgoszcz 2008, s. 275-285; М. Маршалэк, Из исследований над советским польским языком, „Zinatniskie raksti” III, Ryga 2001, s. 171-172; J. Mędelska, M. Marszałek, Z badań nad językiem polonii radzieckiej lat 1917-1939, [w:] Język polski w rozwoju, red. Ł. Szewczyk, M. Czachorowska, Bydgoszcz 2001, s. 111-121; J. Mędelska, M. Marszałek, Język polski na Białorusi Radzieckiej okresu międzywojennego (kilka uwag na goraco), „Acta Baltico-Slavica” t. 27, 2003, s. 63-71; P. To masik, Ideologia w skrócie. Obraz Związku Radzieckiego lat 20. XX wieku utrwalony w skrótowcach rosyjskich, [w:] Język, historia, polityka, red. E. Laskowska, M. Ja racz, Bydgoszcz 2007, s. 161-165; I. Grek-Pabisowa, Z historii słowników polsko-rosyjskich i rosyjsko-polskich, [w:] Leksyka słowiańska na warsztacie językoznawcy, red. H. Popowska-Taborska, Warszawa 1997, s. 61-73.

7 Bruno Jasieński był jednym $\mathrm{z}$ wielu polskich pisarzy, którzy w obawie przed sądami sanacyjnymi wyjechali w latach 30. do Rosji radzieckiej i osiedlili się tam na stałe, zob.: M. Iw a now, Pierwszy naród ukarany. Polacy w Zwiazku Radzieckim 1921-1939, Warszawa-Wrocław 1991, s. 211.

8 „Kultura Mas” 1930, nr 2, s. 5.

9 „Trybuna Radziecka” 1930, nr 46, s. 4.

${ }^{10}$ Ibidem, nr 54, s. 4. 
w Polsce książek. Pracę nad słownikiem zorganizowano w ten sposób, że całość podzielono na dziedziny naukowe, np. wyrazy społeczno-polityczne, prawnicze, techniczne, dalej wydzielono osobno fizykę, chemię i matematykę, medycynę i hygjenę itd. System ten dający niewątpliwie dużą gwarancję dokładnej roboty, jednak wpłynął na terminy poprzednio wyznaczone, jako że częstokroć autor jednego małego działku zatrzymuje zakończenie tej czy innej litery"11.

Początkowo redakcja „Trybuny Radzieckiej” postanowiła zorganizować konkurs na najlepsze ekwiwalenty prezentowanych rosyjskich słów. Ostatecznie wycofano się z tego pomysłu ze względu na trudności z przeprowadzeniem konkursu oraz pośpiech, który był wymagany przez wydawnictwo Sowietskaja Encikłopiedija.

$\mathrm{W}$ nr. $46^{12}$ Józef Krasny przedstawił pierwszą grupę 30 wyrazów rosyjskich, których polskie odpowiedniki nie były, według niego, zbyt udane.

Poniżej zamieszczam spis tych wyrazów wraz z ich polskimi ekwiwalentami, zawartymi w wydanym dwa lata później słowniku Krasnego ${ }^{13}$ :

безалаберность 'niedbałość, opieszałość, rozlazłość, выдвиzams 'wysuwać, wyłaniać', выдвиженеи 'wysunięty, wydźwignięty przez masy, wydwiżeniec', головотяпство 'niedołęstwo, ślamazarność', единоначалие 'jednorządność', загиб 'zagięcie, zakrzywienie, polit. wypaczenie', загибщик 'wypaczeniec', избач 'izbacz, chatnik', колхоз 'kolektyw rolny, kołchoz, kolgosp', мешочник 'workarz, kontrabandzista, spekulant', мещочничество 'przekupnictwo, spekulacja, kontrabanda, workarstwo', мракобес 'obskurant, wstecznik, wróg oświaty', непрерывка 'nieprzerwanka, nieprzerywka, ciągła praca, nieprzerwany, ciągły tydzień pracy', передыика 'wytchnienie, odpoczynek, przerwa, ulga czasowa', перегиб 'przegub, przegięcie, załamanie, skrzywienie, wykrzywienie, spaczenie', перегибщик 'wypaczeniec, odchyleniec', подкулачник 'podkułak, zausznik kułacki', nопyтчик '1. towarzysz podróży; 2. sympatyk; sowietyzujący pisarz, artysta', пораженчество 'defetyzm', прогул 'samowolna przerwa w pracy; łazęgowanie, łazikowanie, wagusowanie, labowanie', прогульщик 'łazik, łazęga, łazuch', расхлябанность 'ślamazarność, mazgajstwo, niezaradność, nieporadność, склока 'swary, waśń, intryga, kłótnia, spór, niesnaska', смьıика 'styk, spójnia, łącznia, spójność', совхоз 'gospodarstwo radzieckie, sowchoz', ударник 'szturmowiec', хвостизм 'wleczenie się w ogonie, chwostyzm', хлебозаготовка 'zakupy zboża, skup zboża', хозяйственник 'działacz (pracownik) gospodarczy, przemysłowy', чистка (аппарата партии) 'czystka, przesiew partji'.

Kolejna grupa słownictwa została zaprezentowana w nr. 54 „Trybuny Radzieckiej"14:

буза 'buza, burda, zamieszanie, rwetes', бузатер 'warchoł, awanturnik, krzykacz', вечеринка 'wieczorek, wieczornica', волокита 'mitręga, ciąganina, przewlekanie', волокитчик 'mitrężnik, maruda', единоличник 'jednostkowiec', командировка

11 Ibidem.

12 Ibidem, nr 46, s. 4.

13 Ю. Красный, Русско-польский...

14 „Trybuna Radziecka” 1930, nr 54, s. 4. 
'komenderówka, komenderowanie, podróż służbowa', лищенеu, 'pozbawieniec, pozbawiony praw', лишенка 'pozbawionka, pozbawiona praw', обломовщина 'obłomowszczyzna, zgnuśniałość, nieruchawość', паникёp 'panikier, popłoch czyniąсу', паникёрство 'panikierstwo', перевоспитать 'wусhować po nowemu, przeszkolić', передышка 'wytchnienie, odpoczynek, przerwa, ulga czasowa', перегиб 'skrzywienie, wykrzywienie, spaczenie' перегибщик 'wypaczeniec, odchyleniec', перераспределение 'ponowny podział', подъёмные (деньги) 'pieniądze na koszta podróży', посиделки 'wieczornice', путёвка 'komenderówka, przepustka', pасхлябанность 'ślamazarność, mazgajstwo, niezaradność, nieporadność', склока 'swary, waśń, intryga, kłótnia', склочник 'warchoł, kłótnik, awanturnik, wichrzyciel', склочничество ${ }^{15}$, смазывать вопрос 'zacierać istotę kwestji', шкурник 'sobek, samolub, dbający tylko o swoją skórę', шкурныцй 'sobkowski', шкурничество 'dbałość o własną skórę; zabieganie o korzyść osobistą'.

Ostatnią grupę wyrazów zamieszczono w nr 60 „Trybuny Radzieckiej” wraz następującym komentarzem redakcji słownika: „W grupie tej pomieściliśmy takie słowa, które mają swoje tłumaczenie, ale niezbyt dokładne, jak np. «вплотную, сплошной, крупный». Komunikujemy, że do redakcji napływają propozycje czytelników «Trybuny Radzieckiej». Wyrazy te ogłosimy po ułożeniu całego słownika, tj. w końcu lata"16.

\section{Oto zaprezentowane wyrazy:}

алиментщица 'otrzymująca (płacąca) alimenta', алиментщцик 'otrzymujący (płacący) alimenta', вплотную 'ściśle, szczelnie, nieruchomo, na fest', вmуз 'wyższa uczelnia (szkoła) techniczna', втузовеu, 'słuchacz techniki, student techniki, politechnik', вуз 'wyższa uczelnia, wyższy zakład naukowy', выходеи, из класса (w słowniku zanotowano выходеи, из буржуазных классов 'wychodzień z klas burżuazyjnych, człowiek pochodzenia burżuazyjnego, pochodzący z burżuazji'), единоличник 'jednostkowiec', заготовка 'przygotowanie, przysposobienie, zaopatrzenie, zasilenie', зажим 'zacisk, ucisk, hamowanie, krępowanie', кровно ${ }^{17}$, кровныцй 'krewny, spokrewniony', крупный 'duży, wielki, znaczny, poważny', лесозаготовка ${ }^{18}$, нагрузка 'obciążenie, nawał pracy, praca dodatkowa, załadowanie', намётка 'szkic, zarys, naznaczenie, znak, znaczek', перевыборы 'ponowne, nowe wybory', прибедняться 'udawać (robić) z siebie biednego, niezamożnego, podawać się za biednego', профодежда 'odzież robocza, pracownicza, zawodowa', промфинплан 'plan przemysłowo-finansowy, promfinplan', самокатчик 'mоtocyklista, kolarz, cyklista', себестоимость 'własny koszt', спецодежда 'odzież zawodowa, robocza', сплошной 'ciągły, nieprzerwany, ustawiczny, całkowity, zupełny', фабзаяи, 'uczeń szkoły fabrycznej', ходатаŭ 'pośrednik, orędownik, protektor, obrońca'.

15 Brak słowa w słowniku.

16 „Trybuna Radziecka” 1930, nr 60, s. 4.

17 Brak słowa w słowniku.

18 Brak słowa w słowniku. 
W 1933 roku, po ukazaniu się słownika rosyjsko-polskiego, w nr 89 „Trybuny Radzieckiej" zamieszczono krótką notatkę od redakcji słownika, podpisaną przez S. Borskiego i J. Starkę ${ }^{19}:$ „Redakcja dokładała wszelkich starań, żeby możliwie obficie przedstawić słowozbiór społeczno-polityczny, szczególny nacisk kładąc zarówno na polsko-sowiecką terminologię, jako też na wszelkie przejawy kultury proletariackiej na łamach polskiej, zagranicznej, legalnej i nielegalnej prasy robotniczej. [...] Jednakowoż redakcja dokładnie zdaje sobie sprawę z tego, że słownik nie mógł uniknąć szeregu braków i usterek, ze względu na rozmiar (pełny słownik musiałby zawierać około 150 tysięcy słów), w związku z szybkim rozwojem języka epoki rewolucji proletariackiej i zaostrzonej walki klasowej i wreszcie wobec tego, że dany słownik jest pierwszą próbą systematyzacji materiałów, dotąd słownikowo nieusystematyzowanych. Redakcja słownika zwraca się tą drogą do szerokiego ogółu pracowników polskich, posługujących się słownikiem o nadsyłanie wszelkich swych spostrzeżeń i uwag o zauważonych omyłkach i brakach [...]"20.

Wkrótce po ukazaniu się słownika pojawiły się słowa krytyki pod jego adresem. Główne zarzuty dotyczyły sowietyzmów, czyli leksyki nazywającej nowe realia radzieckie. W nr. 1 „Kultury Mas” z 1933 roku F. Mirecki pisał: „Co się tyczy sowietyzmów, to - naszym zdaniem - redakcja «Słownika» popełniła błąd metodologiczny. «Biorąc za podstawę - czytamy w przedmowie - utarte wyrażenia polsko-radzieckie, w poszczególnych bardzo rzadkich przypadkach redakcja zastępowała używane w praktyce nieudatne, tłumaczenie sowietyzmów przez nowotwory, bardziej odpowiadające charakterowi języka polskiego». Otóż zadaniem każdego słownika jest przedewszystkiem zarejestrowanie, zinwentaryzowanie odpowiedników, istniejących w danym języku, nie zaś tworzenie nowotworów, które, gdyby nawet były udatne, mają tę kardynalną wadę, że nie są nikomu znane. Łacno też może się zdarzyć, że rosjanin, któryby się posiłkował nowotworami «Słownika» niebyłby przez polaków zrozumiany"21.

Z jednej strony zarzucano redakcji wprowadzanie na karty słownika sztucznych nowotworów językowych, $\mathrm{z}$ drugiej, jeszcze w trakcie powstawania słownika, pojawiały się głosy wręcz przeciwne.

Wspomniany wcześniej Bruno Jasieński, czołowy działacz Polonii radzieckiej, nawołując do stworzenia polskiego języka proletariackiego ${ }^{22}$, krytykował język Polaków mieszkających w Rosji radzieckiej, nasycony rusycyzmami i skrótowcami ${ }^{23}$. Okazuje się, że część wyrazów, dla których Jasieński zaproponował nowe tłuma-

19 Zastąpili oni zmarłego Józefa Krasnego.

20 „Trybuna Radziecka” 1933, nr 89, s. 4.

21 „Kultura Mas” 1933, nr 1, s. 5.

22 B. Jasieński, O rewolucję językową, „Kultura Mas” 1929, nr 1/2, s. 11-13; idem, Twórzmy polski język radziecki, „Kultura Mas” 1930, nr 2, s. 5.

${ }^{23}$ Szerzej zob.: J. Mędelska, M. Marszałek, Kułak czy gbur? Rozterki twórców polszczyzny radzieckiej, „Przegląd Polonijny” XXVI, 2000, z. 3, s. 121-139. 
czenia $^{24}$, pojawiła się również na liście leksemów opublikowanych w „Trybunie Radzieckiej”. Wśród rusycyzmów, o których przetłumaczenie prosił Józef Krasny, znalazły się następujące wyrazy: избач, колхоз, подкулачник, прогул, прогульщик, профодежда, совхоз, спецодежда, чистка. Jak piszą Jolanta Mędelska i Marek Marszałek, tylko dwa z zaproponowanych przez Jasieńskiego nowych tłumaczeń trafiły na karty słownika polsko-rosyjskiego z 1931 roku, a mianowicie łazik (zamiast progulszczyk) i kolektyw (zamiast kołchoz). Natomiast w słowniku rosyjsko-polskim z 1933 roku zamieszczono niemal wszystkie nowotwory ( gbur, kolektyw, łazik, łazikowanie, podgburek, przesiew oraz potępione przez Brunona Jasieńskiego chata-czytelnia i izbacz) $)^{25}$.

Ustrój totalitarny panujący w Rosji radzieckiej powodował, że wszelkie odchylenia od polityki partii poddawane były surowej krytyce. Sam Bruno Jasieński i Tomasz Dąbal ${ }^{26}$, którzy nawoływali do stworzenia polskiego języka radzieckiego i wypowiadali się krytycznie pod adresem słownika Józefa Krasnego, również znaleźli się w ogniu krytyki. W nr. 99 „Trybuny Radzieckiej” z 1930 roku czytamy: „Uparte obstawanie tt. Dąbala i Bruno Jasieńskiego za utrzymaniem takich terminów [...] jak «gbur», «świetlica», zamiast «kułak», «chata-czytelnia», całe głupie teorje t. Dąbala, rozwodzone [...] nad tym «włościanin czy chłop», dowodzenie nareszcie tt. Dąbala i Bruno Jasieńskiego, że rozwój polskiej kultury proletarjackiej w Związku Radzieckim możliwy jest tylko jakoby pod warunkiem koordynowania go $\mathrm{z}$ ruchem rewolucyjnym w Polsce, [...] wszystko to jaskrawie przemawia, że ci towarzysze (Dąbal i Bruno Jasieński) nie rozumieją leninowskiej polityki narodowościowej, [...] działają na rękę kułactwu polskiemu, wszystkim szumowinom antyradzieckim, [...] obnażają tym samym swój nagi oportunizm prawicowy w polityce narodowościowej naszej partji” [podpis: Bronisław Marczewski] ${ }^{27}$.

Leksyka wprowadzona na karty moskiewskich słowników jest niezwykle cenna, gdyż reprezentuje żywą polszczyznę radziecką okresu międzywojennego. Znaczna część wyrazów poddanych pod dyskusję czytelników „Trybuny Radzieckiej” znala-

${ }^{24}$ W rubryce „Twórzmy polskie słownictwo rewolucyjne!” w „Kulturze Mas” opublikowano listę sowietyzmów, dla których proponowano nowe ekwiwalenty: przesiew zamiast czystka, świetlica zamiast chata-czytelnia, świetlicowy zamiast izbacz, gbur zamiast kułak, podgburek zamiast podkułacznik, wyrwa zamiast proryw, łazikowanie zamiast progut, łazik zamiast progulszczyk, kolektyw zamiast kołchoz, gosprad zamiast sowchoz, robodzież zamiast profodieżda, fachodzież zamiast spiecodieżda („Kultura Mas" 1930, nr 2, s. 19).

${ }^{25}$ J. Mędelska, M. Marszałek, op. cit. Kułakczy gbur?, s. 137.

${ }^{26}$ Tomasz Dąbal w ramach wymiany więźniów politycznych wyjechał do ZSRR, gdzie został czołowym działaczem Polonii radzieckiej. Szerzej o życiu Dąbala zob.: H. Cimek, Tomasz Dąbal 18901937, Rzeszów 1993, o jego polszczyźnie zob.: T. Graczykowska, Rusycyzmy i sowietyzmy w tekstach Tomasza Dąbala (przedstawiciela polskich komunistów przebywajacych $w$ okresie międzywojennym w ZSRR), [w:] Język, historia, polityka, s. 39-51; eadem, Osobliwa leksyka w książe Tomasza Dąbala „Polacy Związu Radzieckiego”, „Linguistica Bidgostiana”, t. 6, 2009, s. 64-72.

27 „Trybuna Radziecka” 1930, nr 99, s. 4. 
zła odzwierciedlenie na stronach tejże gazety. Sama „Trybuna Radziecka” była centralną gazetą polską w ZSRR w okresie międzywojennym ${ }^{28}$. Wychodziła w Moskwie w latach 1927-1938. Początkowo ukazywała się jako tygodnik, w 1932 roku przekształciła się w gazetę codzienną. W 1930 roku w tym dzienniku pisano: „[...] przed rokiem nasza gazeta wychodziła jako chuderlawy tygodnik o małym formacie, posiadający faktycznie zaledwie paręset miesięcznych prenumeratorów i zaledwie kilkadziesiąt całorocznych i półrocznych [...]. Z chuderlawego tygodnika, wychodzącego niejednokrotnie co dwa tygodnie «Trybuna Radziecka» przekształciła się na normalną gazetę wychodzącą prawie co drugi dzień, t.j. 2 razy w pięciodniówce. [...] W ciągu ostatniego roku doprowadziliśmy nakład naszej gazety średnio do 10000 egzemplarzy, przy czym szereg numerów rozchodził się w nakładzie 30 000, a nawet 50000 egzemplarzy. O ile «Trybuna Radziecka» poprzednio była czasopismem na ogół aktywu, to obecnie posiada ona wyraźny charakter pisma masowego, zawierającego 50-60\% materiału nadesłanego przez robotników i chłopów-kolektywistów. [...] stale wzrasta dział korespondencji robotniczych. «Trybuna Radziecka» coraz bardziej odzwierciedla w ten sposób potrzeby mas, przynosi świeży, oryginalny materiał, jest tworzona przez masy" ${ }^{29}$.

Przejdę teraz do prezentacji materiału leksykalnego wyekscerpowanego z „Trybuny Radzieckiej". Chciałabym tu przedstawić jedynie te rusycyzmy i sowietyzmy, które znalazły się jednocześnie na liście wyrazów opublikowanych przez Józefa Krasnego w „Trybunie Radzieckiej”, oraz te, które przez Brunona Jasieńskiego zostały poddane pod osąd czytelników „Kultury Mas”.

Ciekawe, że na stronicach gazety równolegle pojawiały się zarówno rusycyzmy, o których przetłumaczenie prosił autor słownika, jak i proponowane przez Jasieńskiego nowe polskie odpowiedniki sowietyzmów.

CZYSTKA - PRZESIEW ('„oczyszczanie” jakiegoś środowiska, jakiejś instytucji z niepożądanych elementów, usuwanie tych elementów')

czystka: Wobec tego jest potrzebna powtórna czystka tej komórki - 30/9/2; O swym niegdyś krótkotrwałym należeniu do „Sokoła” [...] mówiłem [...] nawet ostatnio na zebraniu partyjnym, gdy przechodzitem czystkępartji - 30/4/4; Czystka uwolni nas z szeregu zbytecznych elementów [...] - 33/20/3 (leksem ten, oraz jego pochodne, np. czyszczony, wyróżniał się bardzo dużą frekwencją);

przesiew: Do tego [...] obecnie zmierza odbywająca sie „czystka” - przesiew partji - 29/64/1; Pierwsze wyniki przesiewu partji - 29/64/1; Przesiew (czystka) komórki partyjnej wykryt szereg chorobliwych zjawisk [...] - 30/9/2; Przesiew partji na wsi [tytuł] - 30/39/3; Przesiew partji nie był dostatecznie przygotowany - 30/9/2 (kilkanaście wystąpień).

\footnotetext{
28 Szerzej o gazecie zob.: K. Sierocka, op. cit., s. 50-56, M. Iw a now, op. cit., s. 228-229.

29 „Trybuna Radziecka” 1930, nr 49-50, s. 1.
} 
FACHODZIEŻ - SPIECODIEŻDA / SPECODZIEŻ ('odzież ochronna, ubranie robocze')

fachodzież: brak leksemu w „Trybunie Radzieckiej”;

spiecodieżda / specodzież: [...] nie wszyscy robotnicy otrzymali specodzież [...] - 27/1/11; [...] spec-odzież nie wszystkim była wydana [...] - 27/16/11; Spec-odzież $w$ przeszłym roku wydawano $w$ ilościach, uchwalonych przez Ludowy Komisarjat Oświaty Pracy [...] - 27/16/11; To samo dotyczy spec-odzieży - 27/16/11 (zarejestrowano również spec-ubranie: Inne, drobniejsze [postulaty] tycza ulepszenia „specubrania" [...]-29/3/3).

GBUR - KUEAK ('bogaty chłop zatrudniający w gospodarstwie siły najemne, wyzyskujący biedotę wiejską; kapitalista wiejski')

gbur: Gburzy nie śpia [...] - 30/6/3; [...] będzie rozegrana zdecydowana walka z gburem [...] - 30/5/1; [...] gburzy nie chca oddawać zboża [...] - 30/7/2; Gburzy [...] urzadzili cała demonstrację [...] - 30/9/3 (leksem ten, oraz jego pochodne: gburczyk, gburowski, gburo-, gburowstwo, wyróżniał się bardzo dużą frekwencją tekstową, jednak wszystkie przykłady pochodzą tylko z dwóch roczników gazety, a mianowicie z 1929 i 1930 roku, w następnych rocznikach wyraz ten został zastąpiony kułakiem. Początkowo gbur pojawiał się często w złożeniu gbur-kułak, dopiero w dalszych numerach występował już samodzielnie, np.: Biedacy nie zwracaja uwagi na groźby gburów-kułaków [...] - 30/1/3);

kułak: Bezwzględnie zwalczać kułaków [...] - 29/44/4; [...] kontratak kułaków jest odpierany - 29/3/1; Kułacy [...] usiłują terorem $w$ stosunku do biedoty walczyć - 30/1/3; Kułacy chca terorem odstraszyć biedotę od kolektywizacji - 30/1/3 (leksem ten wyróżniał się bardzo dużą frekwencją tekstową).

GOSPRAD - SOWCHOZ ('państwowe gospodarstwo rolne w Związku Radzieckim')

gosprad: Nowa kolej żelazna Meretu-Cherson przechodzi mimo dużych gospradów [...] - 30/75/7 (2 wystąpienia); W kwestji zdawania zboża przez duże gosprady tkwi wielkie niebezpieczeństwo - 30/75/5;

sowchoz: Gospodarstwa kolektywne i sowchozy jako wskaźnik rozwoju sit produkcyjnych [...] - 27/26/9; Jeśli w danym rejonie istnieje majątek radziecki (sowchoz), to można postawić [...] sprawozdanie z działalności tego majątku - 27/34/10; [...] w wyniku [...] rozwoju sowchozów państwo [...] posiada co najmniej 1,5 miljarda pudów zboża [...] - 35/22/1 (leksem o bardzo dużej frekwencji tekstowej).

KOLEKTYW - KOLCHOZ ('spółdzielcze gospodarstwo rolne w Związku Radzieckim')

kolektyw: Polska wieś Gorodniawka połączyła się w jeden kolektyw [...] - 30/1/3; Gburzy-kułacy starali się ja za wszelka cenę odciagnać od kolektywu [...] - 30/1/3; Szczególnie baczna uwage należy zwrócić na premjowanie kontraktantów i kolektywów - 30/101/4 (leksem ten wyróżniał się bardzo dużą frekwencją tekstową); 
kołchoz: Pięciolatka przewiduje ogromny wzrost części (sektoru) rolnictwa tj. „sowchozów" $i$ „kołchozów" - 29/26/1; [...] obszar zasiewów [...] wynosit [...] w kołchozach miljon 390 tys. ha [...] - 29/66/1; Kolchoz hamuje prowadzenie ewidencji pracy [tytul] 31/70/1; W republice jest 17 kołchozów-miljonerów - 38/84/3 (bardzo częste).

\section{LAZIK - PROGULSZCZYK ('bumelant')}

Łazik: Łaziki, marudery i sobki - to najwięksi wrogowie [...] - 30/56/3; Komórka partyjna powinna przekształcić każdego zacofanego robotnika, każdego łazika [...] $w$ dobrego szturmowca [...] - 32/12/2; Kolektywnikom, którzy rzetelnie pracuja, zapisuje się pracodni na równi z łazikami [...] - 32/28/3 (leksem ten wyróżniał się bardzo dużą frekwencją tekstową; również bardzo częste były wyrazy pochodne: łazikostwo, łazikować);

progulszczyk: [...] i oto z pilnego robotnika robi sie "progulszczyk” - 30/110/2; Poszczególne cechy sfotografowały szturmowców i progulszczyków [...] - 31/10/3; [...] około 100 „progulszczyków” nie przychodziło do pracy [...] - 31/22/1.

ŁAZIKOWANIE - PROGUŁ ('niestawienie się do pracy, bumelanctwo')

tazikowanie: [...] brygady szturmowe [...] prowadza walkę [...] z przejawami łazikowania, maruderstwa i sobkostwa [...] - 30/56/3; Proletarajat musi położyć kres łazikowaniu [...] - 30/32/1; Zmobilizować wszystkie brygady rachunku gospodarczego do aktywnej walki, [...] likwidując całkowicie łazikowanie [...] - 32/18/2; [...] nieprawidłowo rozstawiona siła robocza, płynność, masowe łazikowanie, w wyniku tego wszystkiego - tylko 80\% promfinplanu - 32/50/2 (duża frekwencja tekstowa);

progut: [...] stracone wskutek nieusprawiedliwionych opuszczeń („proguły”) miljony dni roboczych [...] - 30/81/2; Nie można powiedzieć, żeby wszystkie "proguly" byty rezultatem braku pracy w warsztatach - 30/110/2; W kombinacie "Standard" w ogóle nie zwalnia się za opóźnienia i "proguty” - 33/32/2; Kierownik cechu kotlarskiego nie reaguje wcale na proguły - 31/16/3; Nie zorganizowano walki $z$ progułami - 33/256/2.

PODKULACZNIK - PODGBUREK ('poplecznik <sprzymierzeniec> kułaków') podkułacznik: [...] zorganizowano pochód [...] zhasłami, które głosity: [...] „tam, gdzie kułak, nepman i podkułacznik, tam nie ma obrony interesów biedoty i średniaka" [...] - 29/7/2; Przeciwko tow. B. występowali podkułacznicy [...] - 29/9/1; [...] znajduje się ona pod wpływem księdza z Olewska i podkułaczników [...] - 29/9/1; Rudkowski grupuje wokót siebie miejscowych gburów-kułaków i podkułaczników - 29/58/3; W r. 1929 ta sama propozycje zgłasza podkułacznik Stefan Kowalczuk [...] - 30/6/1 oraz 29/60/4, 29/62/4;

podgburek: Trudno [...] prowadzić walkę klasowa $z$ klecha, gburem i podgburkiem [...] - 30/53/3.

ROBODZIEŻ - PROFODIEŻDA ('odzież ochronna, ubranie robocze')

profodieżda: brak poświadczenia w „Trybunie Radzieckiej”;

robodzież: brak poświadczenia w „Trybunie Radzieckiej”. 


\section{ŚWIETLICA - CHATA-CZYTELNIA}

świetlica: Wezwać do współzawodnictwa [...] kluby, „świetlice”, szkoły i t.d. - 29/44/4; [...] przyjęty aktywny udział w prowadzeniu akcji o zamknięcie szeregu kościołów [...] celem wykorzystania zwolnionych budynków pod kluby, [...] świetlice - 29/54/1 (29/54/4, 29/58/1);

chata-czytelnia: $50 \%$ chat-czytelni mieści się przy szkołach - 27/7/4; Dzisiaj mamy [...] chaty-czytelnie [...] - 28/30/2; We wsiach, gdzie dotad nie było chaty-czytelni i czerwonych kącików, zorganizowano ostatnio czerwone kąciki - 29/6/4 (leksem o bardzo dużej frekwencji tekstowej, również w tekstach pojawia się izba-czytelnia).

\section{ŚWIETLICOWY - IZBACZ}

świetlicowy: brak poświadczenia w „Trybunie Radzieckiej”;

izbacz: Wartałoby się wypowiedzieć w sprawie [...], aby funkcję kierownika [...] włożyć na sekretarza rady wiejskiej, izbacza [...] - 28/30/9; Prezesem rady wiejskiej został niezamożny średniak, [...] sekretarzem - żona izbacza - 29/6/4; Z inicjatywy izbacza młodzież polska [...] zebrała na radioodbiornik 50 rb - 29/1/4 (29/60/1, 29/52/2).

WYRWA - PRORYW ('opóźnienie, zaległość')

wyrwa: [...] uchwalono [...] zlikwidować wyrwy za kwiecień i maj [...] - 30/75/7; Jedna z przyczyn wyrwy jest złe zaopatrywanie robotników - 32/43/3; Rejon nasz ma wyrwy w tej dziedzinie - 32/88/3 (leksem wyróżniający się bardzo dużą frekwencją tekstową);

proryw: brak leksemu w „Trybunie Radzieckiej”.

Zaledwie tych kilkanaście przykładów pokazuje, jak ważne jest zbadanie wszystkich dostępnych źródeł odzwierciedlających polszczyznę radziecką (zarówno prasy polskiej, jak i materiałów propagandowych, podręczników dla polskich szkół w Rosji radzieckiej, książek napisanych przez polskich komunistów, słowników itd.), co postulowała już w 1997 roku Barbara Szydłowska-Ceglowa ${ }^{30}$. Opis języka prasy polskiej w Rosji radzieckiej, porównanie wyników analizy językoznawczej z opisem języka innych źródeł moskiewskich pozwoli włączyć się do szerokich badań nad stanem polszczyzny radzieckiej w okresie międzywojennym, zwłaszcza że podjęto już próbę opisu polszczyzny mówionej i pisanej na Białorusi Radzieckiej $^{31}$.

${ }^{30}$ B. Szydłowska-Ceglowa, Język polski w Rosji porewolucyjnej i ZSRR (do roku 1935), „Język Polski" LXXVII, 1997, z. 4-5, s. 258.

${ }^{31}$ I. Grek-Pabisowa, M. Ostrówka, B. Biesiadowska-Magdziarz, Język polski na Białorusi Radzieckiej w okresie międzywojennym. Polszczyzna mówiona, Warszawa 2008; eaedem, Język polski na Białorusi Radzieckiej w okresie międzywojennym. Polszczyzna pisana, Warszawa 2008. 


\section{BIBLIOGRAFIA}

T. Graczykowska, Rusycyzmy i sowietyzmy w tekstach Tomasza Dąbala (przedstawiciela polskich komunistów przebywajacych $w$ okresie międzywojennym $w$ ZSRR), [w:] Język, historia, polityka, red. E. Laskowska, M. Ja racz, Bydgoszcz 2007, s. 39-51.

T. Graczykowska, Osobliwa leksyka w książce Tomasza Dąbala „Polacy Związku Radzieckiego”, „Linguistica Bidgostiana”, t. 6, 2009, s. 64-72.

I. Grek-Pabisowa, Z historii słowników polsko-rosyjskich i rosyjsko-polskich, [w:] Leksyka słowiańska na warsztacie językoznawcy, red. H. Popowska-Taborska, Warszawa 1997, s. 61-73.

I. Grek-Pabisowa, M. Ostrówka, M. Biesiadowska-Magdziarz, Język polski na Białorusi Radzieckiej w okresie międzywojennym. Polszczyzna mówiona, Warszawa 2008.

I. Grek-Pabisowa, M. Ostrówka, M. Biesiadowska-Magdziarz, Język polski na Białorusi Radzieckiej w okresie międzywojennym. Polszczyzna pisana, Warszawa 2008.

M. Iwa now, Pierwszy naród ukarany. Polacy w Związku Radzieckim 1921-1939, Warszawa-Wrocław 1991.

B. Jasieński, O rewolucję językową, „Kultura Mas” 1929, nr 1/2, s. 11-13.

B. Jasieński, Twórzmy polski język radziecki, „Kultura Mas”1930, nr 2, s. 5.

J. Męd elska, Nowe, radzieckie realia odzwierciedlone w moskiewskim słowniku rosyjsko-polskim, wydanym w latach 30. ubiegłego wieku, [w:] Język, społeczeństwo, wartości, red. E. Laskowska, I. Benenowska, M. Ja racz, Bydgoszcz 2008, s. 275-285.

J. Mędelska, M. Marszałek, Z badań nad językiem polonii radzieckiej lat 1917-1939, [w:] Język polski w rozwoju, red. Ł. Szewczyk, M. Czachorowska, Bydgoszcz 2001, s. 111-121.

J. Mędelska, M. Marszałek, Język polski na Białorusi Radzieckiej okresu międzywojennego (kilka uwag na gorąco), „Acta Baltico-Slavica” t. 27, 2003, s. 63-71.

J. Mędelska, M. Marszałek, Kułak czy gbur? Rozterki twórców polszczyzny radzieckiej, „Przegląd Polonijny” XXVI, 2000, z. 3, s. 121-139.

K. Sierocka, Polonia radziecka 1917-1939. Z działalności kulturalnej i literackiej, Warszawa 1968.

B. Szydłowska-Ceglowa, Język polski w Rosji porewolucyjnej i ZSRR (do roku 1935), „Język Polski” LXXVII, 1997, z. 4-5, s. 251-258.

P. Tomasik, Ideologia w skrócie. Obraz Związku Radzieckiego lat 20. XX wieku utrwalony w skrótowcach rosyjskich, [w:] Język, historia, polityka, red. E. Laskowska, M. Ja racz, Bydgoszcz 2007, s. 161-165.

J. Wawrzyńczyk, O pewnym źródle dokumentacyjnym słownictwa polskiego, „Poradnik Językowy” 1990, nr 1, s. 58-60.

М. Маршалэк, Из исследований над советским польским языком, „Zinatniskie raksti” III, Ryga 2001, s. 167-173.

Ю. Красный (ред.), Польско-русский словарь, Москва 1931.

Ю. Красный (ред.), Русско-польский словарь, Москва 1933.

Й. Мэндэльска, Проблемы исследования послереволюиионного варианта советского польского языка, „Scando-Slavica”, t. 47, 2001, s. 53-61. 
THE DICTIONARY OF JÓZEF KRASNY AND POLISH LIVING RUSSIAN LANGUAGE IN THE INTERWAR PERIOD (SEVERAL REMARKS ABOUT THE COMPETITION PUBLISHED IN „TRYBUNA RADZIECKA” IN 1930).

\section{SUMMARY}

In 1930 the editor-in-chief of the Russian-Polish Dictionary, Józef Krasny, asked the readers of the newspaper "Trybuna Radziecka", published in Moscow in 1927-1938, to send to the newspaper "Trybuna Radziecka" the best Polish equivalents of presented words. The list of the Rusicisms and the Sovietisms was published in "Trybuna Radziecka" and contained about 90 lexems. In Józef Krasny’s opinion these words had not very good translation in the Soviet Polish language. He described the process of creation of this dictionary in "Trybuna Radziecka". The editor of Russian-Polish dictionary made effort to reflect as closely as possible the language of proletarian revolution, the new realities of life in the Soviet Union. The Russian-Polish Dictionary was criticized by contemporaries. Among them was Bruno Jasieński.

The article presents a lexical material excerpted from the "Trybuna Radziecka". The author tries to show that many of lexems presented in "Trybuna Radziecka" in list of Józef Krasny were in common use in the Soviet variant of Polish language in the years preceding World War II. The author incorporated only these Rusicisms and Sovietisms extracted from the "Trybuna Radziecka" which were presented in newspaper by Józef Krasny and were discussed in the newspaper "Kultura Mas" by Bruno Jasieński. The paper contains 12 pairs of lexems, like czystka - przesiew, gbur - kułak, gosprad - kołchoz, łazik - progulszczyk.

The aim of the article is show that the "Trybuna Radziecka" reflects living Polish language in the post-revolution Soviet Russia.

\section{СЛОВАРЬ ЮЗЕФА КРАСНОГО И ЖИВОЙ ПОЛЬСКИЙ СОВЕТСКИЙ ЯЗЫК В ДВАДЦАТИЛЕТИЕ МЕЖДУ ПЕРВОЙ И ВТОРОЙ МИРОВОЙ ВОЙНОЙ (НЕСКОЛЬКО ЗАМЕЧАНИЙ О КОНКУРСЕ, ОБЪЯВЛЕННОМ ГАЗЕТОЙ „ТRYВUNA RADZIECKA” В 1930 Г.)}

\section{PEЗЮME}

В 1930 году редакция газеты „Trybuna Radziecka”, которая издавалась в Москве, проживающими здесь польскими коммунистами, объявила языковой конкурс. Редактор польско-русских словарей поместил в газете список русских лексем, не имеющих, по его мнению, удачных польских эквивалентов. В список вошли, главным образом, наименования новых советских ре- 
алиий (напр., избач, колхоз, подкулачник, прогул, прогульщик, чистка и др.). Редактор Юзеф Красны обратился к читателям с просьбой присылать в редакцию газеты переводы указанных слов с целью выбора самых удачных эквивалентов и помещения их в подготавливаемом для издания русско-польском словаре.

В статье рассмотрена часть таких слов. Автор пытался показать, что советизмы и руссизмы (заимствования из русского языка), отобраны Ю. Красным были использованы также в языке (польском) газеты „Trybuna Radziecka”. На страницах газеты параллельно появлялись и руссизмы, к которым автор словаря просил подбирать эквиваленты, как и новые польские переводы советской лексики (напр., czystka - przesiew, gosprad - sowchoz, łazik - progulszczyk, wyrwa - proryw).

Słowa kluczowe: język polski w ZSRR, okres międzywojenny, rusycyzmy, sowietyzmy.

Key words: the Polish language in the Soviet Union, period between the wars, Rusicisms, Sovietisms.

Ключевые слова: польский язык в СССР, междувоенный период, „советизмы”. 